\title{
Penerapan Metode Diskusi untuk Meningkatkan Prestasi Belajar PKn Materi Globalisasi
}

\author{
Tarini \\ SDN 1 Benderejo Kecamatan Pogalan Kabupaten Trenggalek \\ Email: tarinispd01@gmail.com
}

\begin{tabular}{l}
\hline Tersedia Online di \\
\hline http://www.jurnal.unublitar.ac.id/ \\
index.php/briliant \\
\hline \\
\hline Sejarah Artikel \\
\hline Diterima pada 2 April 2017 \\
Disetuji pada 5 April 2017 \\
Dipublikasikan pada 1 Mei 2017 \\
Hal. 140 - 146 \\
\hline
\end{tabular}

Kata Kunci:

diskusi, prestasi belajar, pkn

\begin{abstract}
Abstrak: Penetapan Kurikulum Tingkat Satuan Pendidikan (KTSP) diharapkan mampu untuk mewujudkan tujuan pendidikan Nasional, dan guru dalam kurikulum ini dalam pembelajaran berusaha untuk meningkatkan kreativitas siswa menyampaikan gagasan pada pembelajaran dengan menerapkan metode diskusi. Analisis data observasi aspek keterlibatan siswa dalam pembelajaran dengan penerapan metode diskusi pada pembelajaran $\mathrm{PKn}$. Berdasarkan hasil penelitian yang telah dilaksanakan dapat disimpulkan bahwa pembelajaran dengan menggunakan metode Diskusi dapat meningkatkan kemampuan siswa dalam memahami tentang arus globalisasi.
\end{abstract}

Dalam rangka membangun Indonesia seutuhnya diperlukan adanya pembangunan disegala bidang, termasuk bidang pendidikan. Dengan pendidikan diharapkan adanya peningkatan kualitas bangsa yang utuh. Sehingga hal tersebut sesuai dengan tujuan pendidikan nasional, sebagaimana tertera dalam Undangundang RI nomor 20 tahun 2003 bab II pada 3.

Untuk mencapai tujuan tersebut diatas, perlu dijabarkan lagi dalam bentuk silabus. Salah satu faktor yang berperan dalam keberhasilan guru menyampaikan materi untuk meningkatkan prestasi belajar harus dengan metode yang tepat.

Sementara konsep pembelajaran secara terus menerus mengalami perubahan dan perkembangan sesuai dengan ilmu dan tehnologi pendidikan. Metode mengajar saat ini dikenal dengan model pembelajaran, situasi pembelajaran dan prosedur penelitian. Semua faktor secara dinamis berhubungan dalam suatu rangkaian yang terarah dalam rangka membawa siswa mencapai tujuan pembelajaran.

Salah satu upaya peningkatan mutu pendidikan demi menunjang keberhasilan siswa dalam menyongsong era globalisasi adalah dengan adanya penyempurnaan kurikulum. Dan indikator keberhasilan kurikulum ditunjukkan dengan adanya perubahan dengan pola belajar mengajar menjadi kegiatan yang berpusat pada siswa, ketepatan memilih media pendidikan serta ketepatan cara penilaian yang dilakukan oleh guru. Ketepatan penilaian yang dilakukan oleh sekolah, terutama yang berkaitan dengan kelas akan memperlihatkan pencapaian hasil belajar siswa.

Sebagai antisipasi fenomena uraian diatas, Kurikulum Berbasis Kompetensi (KBK) tahun 2004 harus disempurnakan untuk meningkatkan mutu 
pendidikan dan pembelajaran secara Nasional. Dengan demikian tuntutan untuk meneruskan pemutakhiran kurikulum adalah suatu keharusan demi tercapainya tujuan pendidikan nasional yang bermutu. . Penetapan Kurikulum Tingkat Satuan Pendidikan (KTSP) diharapkan mampu untuk mewujudkan tujuan pendidikan Nasional, yaitu terwujudnya sistem, dan iklim pendidikan yang menyeluruh, demokratis bermutu, guna memperteguh akhlak mulia,kreatif, inovatif,berwawasan kebangsaan,cerdas, sehat berdisiplin, serta menguasai ilmu pengetahuan dan teknologi bagi anak bangsa.

Kurikulum Tingkat Satuan Pendidikan (KTSP) adalah kurikulum nasional yang disusun oleh dan dilaksanakan di masing-masing satuan pendidikan. Kurikulum Tingkat Satuan Pendidikan (KTSP) terdiri dari tujuan pendidikan tingkat satuan pendidikan, struktur, dan muatan kurikulum tingkat satuan pendidikan kalender pendidikan, dan silabus. Mata pelajaran pada jenjang pendidikan dasar dan menengah, pada dasarnya dapat dikelompokkan menjadi tujuh, salah satunya adalah kelompok mata pelajaran kewarganegaraan dan kepribadian. Kelompok mata pelajaran ini, diharapkan dapat mempersiapkan peserta didik menjadi warga negara yang memiliki komitmen kuat dan konsisten untuk mempertahankan Negara Kesatuan Republik Indonesia. Hal tersebut sesuai dengan Undang-undang Dasar 1945 pasal 27 ayat (1) "setiap warga negara berhak dan wajib ikut serta dalam upaya pembelaan negara". Harapan tersebut siswa akan mampu memahami serta melaksanakan hak-hak dan kewajibannya untuk menjadi warga negara indonesia yang cerdas, terampil dan berkarakter.

Pasifnya siswa dalam menyampaikan gagasan dalam proses pembelajaran tersebut kemungkinan disebabkan oleh: (1) Siswa terbiasa menerima apa saja gagasan yang diterima oleh guru, (2) Masalah yang disampaikan terlalu sulit bagi siswa, dan (3) Metode penyampaian materi yang dipilih guru untuk pemecahan suatu masalah kurang tepat.

Berkaitan dengan masalah tersebut di atas, guru berusaha untuk meningkatkan kreatifitas siswa menyampaikan gagasan pada pembelajaran dengan menerapkan metode diskusi. Dengan demikian, penerapan metode diskusi ini dapat meningkatan kreatifitas siswa dalam menyampaikan gagasan pada pembelajaran dikelas IV.

\section{METODE}

Penelitian tindakan kelas ini penulis rencanakan berlangsung dua putaran, mengingat bahwa dalam proses pembelajaran penulis memimpin sendiri, sehingga penulis memperkirakan pada akhir putaran kedua semuanya akan tuntas. Keyakinan ini muncul karena penulis mengenal, bahkan paham betul bahwa siswa-siswa kelas IV SDN 1 Bendorejo Kecamatan Pogalan Kabupaten Trenggalek Tahun Pelajaran 2013/2014 mau dan bersemangat untuk diajak maju. Lebih dari itu, penulis meyakini bahwa penerapan metode diskusi di kelas IV SDN 1 Bendorejo Kecamatan Pogalan Kabupaten Trenggalek Tahun Pelajaran 2013/2014, merupakan strategi pembelajaran yang tepat. Perencanaan tindakan dalam penelitian ini dirancang dalam dua tahap sesuai dengan banyaknya putaran yang direncanakan. 


\section{Perencanaan tindakan putaran kesatu}

Perencanaan tindakan pada siklus kesatu disusun atas analisis dan temuan dalam studi pendahuluan, yaitu: (1) Aktvitas dan kerativitas siswa dalam proses pembelajaran kurang, (2) Siswa kurang termotivasi kritis dan cepat, (3) Hasil belajar siswa rendah, (4) Strategi pembelajaran yang diterapkan belum tepat.

\section{Perencanaan tindakan pada siklus kedua}

Perencanaan tindakan pada putaran ini disusun berdasarkan refleksi hasil observasi pembelajaran putaran kesatu. Pada garis besarnya memusatkan pada sesuatu yang belum dapat terlaksana dengan baik sesuai dengan harapan tanpa mengurangi perhatian pada bagian-bagian yang sudah berjalan dengan baik.

Pada kegiatan ini peneliti melakukan kegiatan penelitian yang sesungguhnya, penelitian melakukan kegiatan awal, yang disebut sebagai pratindakan. Kegiatan pratindakan merupakan kegiatan pendahuluan yang dilakukan oleh peneliti. Kegiatan ini sebagai upaya untuk mengetahui permasalahan yang timbul dalam proses kegiatan pembelajaran. Langkahlangkah yang dilakukan oleh peneliti dalam melaksanakan kegiatan ini adalah melakukan pengamatan terhadap kondisi-kondisi di dalam kelas pada saat kegiatan pembelajaran berlangsung. Perilaku yang dapat diamati antara lain: metode pembelajaran yang digunakan, adanya siswa yang malas mengikuti kegiatan pembelajaran, merasa mengantuk, sering gaduh, malas mengemukakan gagasan, hasil belajar atau prestasi belajar selalu rendah.

Apabila kondisi siswa dalam kegiatan pembelajaran seperti yang disebutkan di atas, maka ada permasalahan yang serius yang dihadapi oleh siswa dalam kegiatan pembelajaran. Guru perlu melakukan upaya lebih lanjut untuk dapat meningkatkan motvasi belajar siswa, sehingga prestasi belajarnya akan meningkat. Maka yang dapat dilakukan oleh guru adalah menemukan dan mendata permasalahan yang timbul pada saat kegiatan pembelajaran.

\section{Pelaksanaan Tindakan}

Pelaksanaan kegiatan dalam penelitian tindakan kelas ini dibagi dalam dua siklus. Setiap siklus terdiri dari dua pertemuan. Langkah-langkah penelitian yang akan dilaksanakan pada masing-masing siklus dalam penelitian tindakan kelas ini mengacu pada model yang dikembangkan oleh Kemmis dan Taggart dalam Syaiful Rachman (2006 :29) yang meliputi: (a) menyusun perencanaan, (b) melaksanakan tindakan, (c) pengamatan, dan (d) refleksi.

\section{Pengamatan}

Pengamatan dilakukan bersamaan dengan tindakan pelaksanaan pembelajaran. Tujuan diadakannya pengamatan adalah untuk mengenali, merekam, mendokumentasikan semua indikator baik proses maupun hasil perubahan yang mendokumentasikan semua indikator baik proses maupun hasil perubahan yang terjadi sebagai akibat dari tindakan yang direncanakan dan sebagai efek samping.

Kegiatan pengamatan meliputi: perencanaan pembelajaran, pelaksanaan tindakan atau pelaksanaan proses pembelajaran dan sikap siswa dalam mengikuti proses pembelajaran, serta hasil pembelajaran yang berupa nilai hasil tes. Kegiatan-kegiatan yang merupakan proses dan hasil tindakan diamati dengan 
menggunakan instrument yang telah dipersiapkan sebelumnya. Data tersebut selanjutnya dijadikan dasar untuk menyusun tindakan pada siklus berikutnya dan penyusunan laporan penelitian tindakan kelas.

\section{Refleksi}

Refleksi dilakukan pada akhir setiap tindakan. Kegiatan ini dilakukan untuk mendiskusikan tindakan yang telah dilakukan. Hal-hal yang perlu didiskusikan adalah, (1) Menganalisa tindakan yang baru dilaksanakan, (2) Mengulas dan menjelaskan perbedaan rencana tindakan yang telah dilakukan, dan (3) Melakukan interpretasi, pemaknaan, dan penyimpulan data yang diperoleh.

Hasil refleksi digunakan sebagai masukan pada pelaksanaan tindakan berikutnya serta digunakan sebagai landasan untuk memodifikasi, penyempurnakan, dan menyusun rencana pembelajaran siklus selanjutnya.

Dalam peneliti tindakan kelas menggunakan pendekatan kualitatif, kehadiran peneliti mutlak diperlukan sebagai instruksi utama. Peneliti berperan sebagai perencana tindakan, pelaksana tindakan, pengumpul data, penafsir data, pemakna data, dan pelapor temuan peneliti.

Sedangkan untuk menjamin objektifitas data, kolaborator atau yang bertindak sebagai observasi juga dilibatkan untuk pengumpul data. Data yang dikumpulkan oleh observer adalah data pengamatan tentang kegiatan guru dalam kegiatan pembelajaran.

Penelitian tindakan kelas dilaksanakan di SDN 1 Bendorejo Kecamatan Pogalan Kabupaten Trenggalek Tahun Pelajaran 2013/2014. Sedangkan subjek peneliti yang akan dijaring datanya siswa kelas IV pada semester II (genap) Tahun Pelajaran 2013/2014 jumlah siswa kelas IV SDN 1 Bendorejo Kecamatan Pogalan Kabupaten Trenggalek ada 24 siswa.

Instrumen penelitian yang digunakan dalam penelitian tindakan kelas ini meliputi, (1) Lembar pre-test, (2) Angket siswa, (3) Lembar observasi, (4) Perangkat pembelajaran.

Sesuai dengan pendekatan yang digunakan dalam penelitian ini, yaitu penelitian kualitatif. Dalam penelitian ini analisis data dilakukan dengan menggunakan metode analisis kualitatif. Dalam penelitian ini analisis data dilakukan secara terus menerus selama proses dan setelah pengumpulan data. Moleong (1998: 89) mengatakan, bahwa analisis data kualitatif dilakukan dalam satu proses, berarti analisa data sudah dapat dilakukan sejak pengumpulan laporan penelitian.

\section{HASIL}

Observasi awal dilakukan oleh tim peneliti, dari hasilnya diketahui bahwa keterlibatan siswa dalam pembelajaran sangat rendah, pembelajaran didominasi oleh guru. Pretes dilaksanakan oleh peneliti, setelah dinilai diketahui bahwa nilai hasil tes prestasi belajar siswa dalam pembelajaran PKn masih sangat rendah jauh dari kriteria ketuntasan yang ditetapkan sekolah.

Dari hasil angket diketahui bahwa metode pembelajaran yang digunakan oleh guru selama ini kurang melibatkan siswa dalam pcmbelajaran dan kurang menyenangkan. Dari paparan data dapat diketahui bahwa nilai hasil rata-rata 60,42 termasuk kategori baik, namun masih di bawah kriteria ketuntasan belajar yang ditetapkan yakni 70 . 


\section{Kegiatan Pelaksanaan Tindakan Siklus 1}

Pelaksanaan tindakan pertemuan ke-I dilangsungkan tanggal 10 dan 17 Pebruari 2014 sesuai dengan rencana yang telah dipersiapkan sebelumnya, dengan mengikuti skenario pembelajaran yang telah ada. Kegiatan yang dilakukan dalam pembelajaran pertemuan ke-1 tanggal 10 Pebruari 2014

Siklus I direncanakan berlangsung 2 pertemuan yakni pada tanggal 10 dan 17 Pebruari 2014. Rencana kegiatan yang akan dilakukan adalah melaksanakan metode diskusi, melakukan pengamatan, dan refleksi.

Skor penilaian observasi keterampilan guru yang dilakukan dengan dua observer diketahui hasil pengamatan sebesar38. Persentasinya 73,08\%, masuk dalam kategori baik. Pertemuan II dilaksanakan tanggal 17 Pebruari 2014 dengan kegiatan, (1) Guru menanyakan materi sesuai dengan rencana pembelajaran, (2) Siswa menjawab pertanyaan guru, (3) Guru menjelaskan singkat tentang materi, (4) Mengadakan evaluasi dengan tes tulis. Dari hasil diketahui bahwa nilai rata-rata test siklus I yang diperoleh siswa sebesar 74,17 lebih baik dari nilai sebelum siklus 60,42. Siswa yang tuntas belajar dalam siklus I ada 18 anak berarti $75 \%$, dan masuk pada kategori baik. Dua guru pcndamping melakukan pengamatan waktu pelaksanaan penelitian. Pengamat memperhatikan gejala yang menyebabkan penurunan keterlibatan siswa dalam pembelajaran. Dari tabel 4.4 diketahui bahwa nilai partisipasi siswa dalam pembelajaran mencapai $65,38 \%$ masuk dalam kategori baik namun belum maksimal.

\section{Kegiatan Pembelajaran Siklus II}

Siklus II direncanakan berlangsung 2 pertemuan yakni pada tanggal 3 dan 10 Maret 2014. perencanaan dibuat rinci agar mudah dilaksanakan dan mendapatkan hasil yang maksimal. Pertemuan pertama dilaksanakan pada tanggal 3 Maret 2014 Pelaksanaan tindakan dilangsungkan sesuai dengan rencana yang telah dipersiapkan sebelumnya, dengan mengikuti skenario pembelajaran yang telah ada.

Skor penilaian observasi keterampilan guru hasil pengamatan sebesar 46,5 dari skor maksimal 60 . Persentasinya $89,42 \%$ berarti lebih baik dari siklus I sebesar 73,08\%. Pertemuan II dilaksanakan pada tanggal 10 Maret 2014, dengan kegiatan inti 1) Guru menanyakan materi diskusi, 2) Siswa menjawab pertanyaan guru, 3) Guru menjelaskan secara singkat materi yang sudah didiskusikan, dan 4) Melakukan evaluasi dengan tes.

Dari hasil diketahui bahwa nilai rata-rata test siklus II yang diperoleh siswa sebesar 87,5. Siswa yang tuntas belajar dalam siklus II ada 24 anak berarti $100 \%$. Pengamatan Kegiatan pengamatan dilakukan dua orang guru pendamping ketika pelaksanaan penelitian sedang berlangsung. Skor hasil pengamatan dua guru pendamping dijumlah kemudian dicari rata-rata skor. Daftar keterlibatan siswa dalam pembelajaran siklus II Dari tabel 4.7 diketahui bahwa nilai partisipasi siswa dalam pembelajaran mencapai $88.46 \%$ masuk dalam kategori sangat baik.

\section{PEMBAHASAN}

\section{Siklus I}

Dari hasil pengamatan keterampilan guru dalam pembelajaran diketahui 
bahwa nilai yang diperoleh 38 yang berarti 73,08 \% termasuk dalam kategori baik namun belum maksimal.

Dalam siklus I peningkatan prestasi belajar siswa dari 10 butir soal yang belum dapat dikerjakan dengan baik nomor 2, dan 3, anak yang mencapai ketuntasan 15 anak persentasinya 71,43\% termasuk kategori baik, namun hasilnya belum maksimal.

Hasil refleksi tentang peningkatan keterlibatan siswa dalam pembelajaran dengan metode diskusi butir-butir yang diamati partisipan ada 13 . Berdasarkan penilaian partisipan dalam lembar pengamatan yang belum terlaksana dengan baik butir 4,6,9 dan 10 .

\section{Siklus II}

Hasil pengamatan keterampilan guru dalam pembelajaran diketahui bahwa nilai yang diperoleh 46 yang berarti 88,46\%. Semua butir kegiatan sudah terlaksana dengan baik. Dalam siklus II peningkatan prestasi belajar siswa dari 10 butir soal dapat dikerjakan semuanya, nilai rata-ratanya 88,10 sedang anak yang mencapai ketuntasan 21 anak persentasinya $100 \%$ termasuk kategori sangat baik dan maksimal.

Hasil refleksi tentang peningkatan keterlibatan siswa dalarn pembelajaran dengan metode diskusi butir-butir yang diamati partisipan ada 13 . Semua butir telah terlaksana dengan baik, nilai yang didapat 46,46 dengan persentasi sebesar $88,46 \%$ dengan kategori sangat baik.

\section{Pembahasan Keseluruhan}

Hasil analisis data observasi aspek keterampilan guru dalam penerapan metode diskusi pada pembelajaran PKn. Pada putaran 1 diperoleh nilai rata-rata dari dua observer mencapai 38 dari nilai ideal $52=(4 \times 13)$. Dari hasil observasi kegiatan pembelajaran dicari persentasi nilai rata ratanya, lalu dibandingkan dengan kriteria taraf keberhasilan. Pada putaran ke dua diperoleh nilai rata-rata dari dua observer mencapai 46,5 dari nilai ideal 52 (4 x 13). Dari hasil observasi kegiatan pembelajaran dicari persentasi nilai rata-ratanya, lalu dibandingkan dengan kriteria taraf keberhasilan.

Analisis data observasi aspek keterlibatan siswa dalam pembelajaran dengan penerapan metode diskusi pada pembelajaran PKn

Pada putaran ke satu diperoleh nilai rata-rata dari dua observer mencapai 34 dari nilai ideal $52=(4 \times 13)$.

Nilai konversi hasil observasi sebagai berikut:

$\mathrm{NR}=75 \%--100 \%$ : sangat baik

$\mathrm{NR}=50 \%--75 \%$ : baik

$\mathrm{NR}=25 \%-50 \% \quad:$ cukup

$\mathrm{NR}=0 \%--\quad 25 \%$ : kurang

Nilai prosentasinya $=34 / 52 \times 100 \%=65,38 \%$ termasuk "baik".

Pada putaran II diperoleh nilai rata-rata dari dua observer mencapai 46 dari nilai ideal 52 (4 x 13). Selanjutnya dipersentasi. Nilai persentasinya $=46 / 52 \times 100 \%=88,46 \%$ termasuk "sangat baik".

Pada analisis prestasi belajar siswa dalam pembelajaran PKn dengan penerapan metode diskusi, putaran pertama diperoleh nilai rata-rata yang dicapai 
siswa 73,33 dari nilai maksimal 100. Sedang siswa yang mcncapai ketuntasan individual scbanyak 15 orang siswa dari jumlah seluruh siswa 24 orang.

Persentasi ketuntasannya $=15 / 21$ x $100 \%=71,43 \%$ berarti " tuntas", cuman belum maksimal. Pada putaran ke dua / terakhir nilai rata-rata yang dicapai siswa mencapai $88,10 \%$ dari nilai maksimal 100 . Sedang siswa yang mencapai ketuntasan individual 21 orang dari jumlah siswa 24 orang. Persentasi ketuntasannya $=21 / 21 \times 100 \%=100 \%$ berarti "tuntas".

\section{KESIMPULAN}

Penerapan metode diskusi pada mata pelajaran PKn efektif dalam meningkatkan prestasi belajar siswa kelas V di SDN 1 Bendorejo. Hal ini dibuktikan dengan ketuntasan yang signifikan di akhir siklus II.

\section{SARAN}

Kajian dalam penelitian ini masih terbatas pada subjek penelitian yaitu siswa kelas IV SD, diharapkan bagi penelitian lanjutan agar meneliti subjek dengan tinjauan yang lain.

\section{DAFTAR RUJUKAN}

Pri Subekti, 2007. Pedoman Penulisan Skripsi dan Laporan Penelitian STKIP PGRI Trenggalek

Arikunto, Suharsimi. 1987. Dasar-Dasar Evaluasi Pendidikan. Jakarta: Penerbit Bina Aksara.

Asy'ari, dkk. 2005. Pendidikan Kewarganegaraan dan Pengetahuan Sosial untuk SD kelas IV. Jakarta: Penerbit Erlangga

Departemen Pendidikan dan Kebudayaan, Tim Penyusun Kamus Pusat Pembinaan dan Pengembangan Bahasa. 1989. Kamus Besar Bahasa Indonesia. Jakarta: Balai Pustaka.

Depdiknas. 2003. Kurikulum 2004 Sekolah Dasar dan Madrasah Ibtidaiyah. Jakarta.

Kaelan, H. 2002. Pendidikan Kewarganegaraan Untuk Perguruan Tinggi. Yogyakarta: Paradigma

Nasution, Noehi, dkk. 1995. Materi Pokok Psikologi Pendidikan. Jakarta: Penerbit Universitas Terbuka, Depdikbud.

Sanjaya, Wina. 2006. Strategi Pembelajaran Berorientasi Standar Proses Pendidikan. Jakarta: Kencana

Semiawan, Conny, dkk. 1990. Pemdekatan Ketrampilan Proses (Bagaimana Mengaktifkan Siswa Dalam belajar?). Jakarta: Penerbit PT Gramedia. 